\title{
IMPLEMENTASI SISTEM PAKAR FORWARD CHAINING UNTUK IDENTIFIKASI DAN TINDAKAN PERAWATAN JERAWAT WAJAH
}

\author{
Deddy Kusbianto ${ }^{1}$, Rizky Ardiansyah ${ }^{2}$, Dzaki Alwan Hamadi ${ }^{3}$ \\ 1,2,3 Program Studi Teknik Informatika, Jurusan Teknologi Informasi, Politeknik Negeri Malang \\ 1deddy_kusbianto@polinema.ac.id, 2rizky.computerscience@gmail.com, ${ }^{3}$ positiveyouth94@gmail.com
}

\begin{abstract}
Abstrak
Jerawat adalah suatu keadaan di mana pori-pori kulit tersumbat sehingga menimbulkan kantung nanah yang meradang. Kemungkinan besar perubahan hormonal yang merangsang kelenjar minyak di kulit yang menjadi penyebab timbulnya jerawat. Jerawat merupakan penyakit kulit yang cukup besar jumlah penderitanya. Seringkali orang awam mengalami kesulitan dalam melakukan proses identifikasi antara penyakit jerawat dengan penyakit yang mirip dengan jerawat, karena gejala yang ditimbulkan dari penyakit hampir sama. Berdasarkan permasalahan tersebut, perlu adanya pengembangan sistem pakar untuk identifikasi dan tindakan perawatan jerawat wajah menggunakan metode forward chaining. Sistem yang dirancang dan diimplementasikan berbasis Dekstop, menggunakan bahasa pemrograman Visual Basic, dan basis data XAMPP, dengan berisikan 7 data penyakit, 32 data gejala penyakit dan 18 data tindakan pengobatan penyakit. Sistem ini juga telah diuji coba dan divalidasi oleh pakar serta beberapa user. Hasilnya didapatkan persentase sebesar $83.3 \%$ yang menunjukan bahwa aplikasi sistem pakar ini cukup efektif.
\end{abstract}

Kata Kunci : Sistem Pakar, Metode Forward Chaining, Identifikasi Jerawat, Tindakan Pengobatan Jerawat

\section{Pendahuluan}

Jerawat adalah masalah kulit yang ditandai dengan munculnya bintik-bintik pada beberapa bagian tubuh, seperti wajah, leher, punggung, dan dada. Bintik-bintik tersebut dapat berkisar mulai dari yang ringan, hingga bintik-bintik parah yang berisi nanah dan kista. Selain ditandai dengan gejala seperti kulit berminyak dan munculnya bintik-bintik, terkadang jerawat juga menyebabkan kulit terasa panas dan sakit saat disentuh. Ada beberapa bagian pada tubuh yang biasa ditumbuhi jerawat dan yang paling umum adalah wajah. Jerawat merupakan kondisi yang umum, artinya sebagian besar orang pernah mengalaminya. Pengetahuan mengenai penyakit jerawat yang diketahui oleh orang awam sangat terbatas dan masih banyak orang yang kurang mengerti dalam mengidentifikasi penyakit jerawat dan penyakit yang mirip dengan jerawat. Dengan pengembangan sistem pakar diharapkan membantu orang awam untuk mengidentifikasi penyakit jerawat sebelum dilakukan tindakan oleh dokter ahli.

Pengetahuan orang awam dalam melakukan tindakan perawatan terhadap penyakit jerawat juga masih sangat terbatas. Apabila seseorang salah dalam melakukan tindakan perawatan, maka bisa menyebabkan penyakit tersebut semakin parah karena tindakan perawatan dari setiap jenis penyakit berbeda-beda walaupun keluhannya hampir sama. Dengan pengembangan sistem pakar ini pula diharapkan dapat membantu sebagai pertolongan pertama bagi orang awam untuk mengurangi resiko terjadinya kesalahan tindakan perawatan jerawat.

Pada penelitian sebelumnya yang berjudul "Analisis Metode Forward Chaining Dalam Sistem Pakar Diagnosa Penyakit Pada Hewan Sapi” telah membahas tentang penerapan metode forward chaining untuk sistem pakar dengan objek penyakit hewan sapi Prasetyo, dkk (2014). Akurasi sistem pakar tersebut telah diuji berdasarkan 10 data yang ada. Penelitian tersebut mendapatkan hasil akurasi dengan nilai akurasi $90 \%$ yang menunjukkan bahwa sistem pakar tersebut berfungsi dengan baik sesuai dengan diagnosa pakar. Dengan tingkat akurasi yang dikategorikan cukup baik tersebut, metode Forward Chaining dapat dikatakan berhasil dengan cukup baik terhadap diagnosis penyakit sapi. Berdasarkan permasalahan tersebut, maka dirasa perlu untuk menerapkan metode Forward Chaining dalam sebuah sistem yang dapat meniru sistem berfikir seorang pakar atau dokter spesialis penyakit jerawat wajah. Cara kerja dari metode forward chaining ini dimulai dengan memasukkan sekumpulan fakta yang 
diketahui ke dalam memori kerja (working memory) yang berupa fungsi-fungsi untuk menjalankan forward chaining itu sendiri, kemudian menurunkan fakta baru berdasarkan aturan yang premisnya cocok dengan fakta yang diketahui untuk menghasilkan suatu kesimpulan. Di dalam kasus ini metode forward chaining dapat membantu proses identifikasi dengan mencocokkan gejala dari suatu penyakit sesuai dengan aturan yang ada. Setelah penyakit tersebut teridentifikasi, maka sistem pakar ini akan melanjutkkan mengenai cara tindakan perawatan dari penyakit yang telah teridentifikasi tersebut.

\section{Landasan Teori}

\subsection{Jerawat}

Jerawat adalah suatu kondisi kulit yang tidak normal di mana terjadi infeksi dan radang pada kelenjar di minyak pada kulit manusia. Dalam dunia kedokteran jerawat diartikan sebagai suatu keadaan di mana pori-pori kulit tersumbat sehingga menimbulkan kantung nanah yang meradang. Jerawat adalah penyakit kulit yang cukup besar jumlah penderitanya. Menurut seorang peneliti masalah jerawat ternama di dunia, berpendapat bahwa tak ada satu orang pun di dunia yang melewati masa hidupnya tanpa sebuah jerawat di kulitnya. Kemungkinan penyebabnya adalah perubahan hormonal yang merangsang kelenjar minyak di kulit.

Perubahan hormonal lainnya yang dapat menjadi pemicu timbulnya jerawat adalah masa menstruasi, kehamilan, pemakaian pil KB, dan stres. Sumber penyebab timbulnya penyakit jerawat biasanya terjadi karena hal-hal seperti adanya sumbatan lapisan kulit mati pada pori-pori yang terinfeksi. Kulit mati yang menumpuk atau terakumulasi akan menyebabkan tersumbatnya folikel dan pori pori. Hal tersebut bisa menyebabkan jerawat karena tidak ada jalan keluar bagi kelenjar minyak dan akan menyebabkan terbentuknya komedo.

Kelenjar minyak yang diproduksi terlalu berlebih juga bisa menjadi salah satu penyebab timbulnya jerawat. Kelenjar minyak yang terlalu berlebihan ini bisa saja dimungkinkan karena salah makan atau memang sudah menjadi genetik seorang penderita jerawat. Dengan banyaknya kelenjar minyak maka munculnya kelenjar minyak akan lebih banyak sehingga kemungkinan tersumbatnya folikel dan pori-pori kulit pun akan semakin banyak sehingga resiko terserang jerawat semakin besar.

Jerawat tidak melulu muncul karena kotor, melainkan lebih disebabkan faktor dari dalam tubuh. Jerawat timbul karena kelenjar minyak yang berlebih tersebut bercampur dengan sel kulit mati. Ketika selsel kulit itu bercampur dengan jumlah sebum yang sudah meningkat, maka campuran yang tebal dan lengket itu dapat membentuk penyumbat yang menjadi bintik hitam atau putih. Banyak orang yang beranggapan, bahwa jerawat hanya menyerang muka, tetapi jerawat bisa juga menyerang bagian tubuh lain, seperti di bagian punggung, dada dan lengan atas Huda, S. (2014).

Banyak beberapa penyakit yang dikategorikan mirip dengan jerawat karena gejala yang ditimbulkan dari penyakit tersebut hampir sama dengan gejala yang ditimbulkan oleh jerawat. Berikut adalah beberapa jenis penyakit jerawat dan penyakit yang mirip dengan jerawat beserta cara pencegahannya.

\section{a. Acne Vulgaris}

Acne Vulgaris adalah penyakit yang mempengaruhi kelenjar minyak di kulit. Lubang kecil atau pori-pori pada kulit saling terhubung dengan dengan kelenjar minyak di bawah kulit. Kelenjar ini yang membuat zat berminyak yang disebut sebum. Di dalam folikel, minyak membawa sel kulit mati ke permukaan kulit. Jika folikel pada kelenjar kulit tersumbat, maka menyebabkan tumbuhnya jerawat di permukaan kulit. Sebagian besar jerawat ditemukan di wajah, leher, punggung, dada, dan bahu Miller, L. (2014).

\section{b. Rosacea}

Rosacea adalah penyakit jangka panjang yang mempengaruhi kulit dan terkadang juga mempengaruhi mata. Gejala penyakit ini meliputi kemerahan pada kulit, munculnya jerawat pada kulit, dan pada tahap selanjutnya menyebabkan kulit menjadi lebih tebal. Pada sebagian besar kasus, rosacea hanya mempengaruhi wajah Miller, L. (2014).

\section{c. Perioral dermatitis}

Perioral dermatitis adalah masalah pada kulit wajah yang umum terlihat pada wanita dewasa dan jarang sekali terjadi pada pria. Sekelompok bintik merah gatal atau lembut tampak paling sering muncul di sekitar mulut dan hidung. Terkadang bintik merah juga muncul di sekitar mata Miller, L. (2014).

\section{d. Pityrosporum folliculitis}

Pityrosporum folliculitis adalah kondisi kulit yang disebabkan oleh infeksi oleh ragi pityrosporum. Gejala sering muncul pada kulit area batang atas termasuk bagian belakang, dada, lengan dan kadang leher sering terpengaruh dan kondisi ini sering terlihat pada orang dewasa muda usia paruh baya. Diagnosisnya didasarkan pada papulopustula pruritus (gatal) yang ditemukan pada pola folikular di daerah ini Sharquie, E. K., dkk (2012).

e. Keratosis Pilaris 
Kondisi ini kadang muncul ketika seseorang menerima pengobatan jangka panjang antibiotik untuk jerawat. Antibiotik mengubah keseimbangan normal bakteri dalam hidung, hingga menyebabkan pertumbuhan berlebih dari organisme berbahaya (bakteri gram negatif). Pada kebanyakan orang, hal ini tidak menimbulkan masalah, dan flora dalam hidung biasanya kembali hadir ketika penggunaan antibiotik telah dihentikan. Namun bakteri gram negatif dapat menyebar dan menyebabkan lesi jerawat baru yang cukup parah Hospenthal, Tania Von (2014).

f. Gram-negative folliculitis

Kondisi ini kadang muncul ketika seseorang menerima pengobatan jangka panjang antibiotik untuk jerawat. Antibiotik mengubah keseimbangan normal bakteri dalam hidung, hingga menyebabkan pertumbuhan berlebih dari organisme berbahaya (bakteri gram negatif). Pada kebanyakan orang, hal ini tidak menimbulkan masalah, dan flora dalam hidung biasanya kembali hadir ketika penggunaan antibiotik telah dihentikan. Namun bakteri gram negatif dapat menyebar dan menyebabkan lesi jerawat baru yang cukup parah Daniella, S. T., dkk (2011).

\section{g. Pseudofolliculitis}

Pseudofolliculitis bisa terjadi disebabkan oleh rambut yang tumbuh ke dalam. Peradangan biasanya terlihat pada wajah dan leher. Kondisi ini dapat meninggalkan bekas luka gelap yang mengangkat (keloid) Hospenthal, T. V. (2014).

\subsection{Forward Chaining}

Forward Chaining adalah teknik pencarian yang dimulai dengan fakta yang diketahui, kemudian mencocokkan fakta-fakta tersebut dengan bagian IF dari rules IF-THEN. Bila ada fakta yang cocok dengan bagian IF, maka rule tersebut dieksekusi. Bila sebuah rule dieksekusi, maka sebuah fakta baru (bagian THEN) ditambahkan ke dalam database. Setiap kali pencocokan, dimulai dari rule teratas. Setiap rule hanya boleh dieksekusi sekali saja. Proses pencocokan berhenti bila tidak ada lagi rule yang bisa dieksekusi. Pendekatan dalam pelacakan dimulai dari informasi masukan dan selanjutnya mencoba menggambarkan kesimpulan, pelacakan kedepan mencari fakta yang sesuai dengan bagian IF dari aturan IF-THEN. Dengan metode forward chaining dari pendekatan dan aturan yang telah dihasilkan dapat ditinjau oleh para ahli untuk diperbaiki atau dimodifikasi untuk memperoleh hasil yang lebih baik Verina, W. (2015).

Algoritma forward chaining adalah satu dari dua metode utama reasoning (pemikiran) ketika menggunakan inference engine (mesin pengambil keputusan) dan bisa secara logis dideskripsikan sebagai aplikasi pengulangan dari modus ponens (satu set aturan inferensi dan argumen yang valid). Forward chaining mulai bekerja dengan data yang tersedia dan menggunakan aturan-aturan inferensi untuk mendapatkan data yang lain sampai sasaran atau kesimpulan didapatkan. Mesin inferensi yang menggunakan forward chaining mencari aturanaturan inferensi sampai menemukan satu dari antecedent (dalil hipotesa atau klausa IF - THEN) yang benar. Ketika aturan tersebut ditemukan maka mesin pengambil keputusan dapat membuat kesimpulan, atau konsekuensi (klausa THEN), yang menghasilkan informasi tambahan yang baru dari data yang disediakan. Mesin akan mengulang melalui proses ini sampai sasaran ditemukan. Forward chaining adalah contoh konsep umum dari pemikiran yang dikendalikan oleh data (data-driven) yaitu, pemikiran yang mana fokus perhatiannya dimulai dari data yang diketahui. Forward chaining bisa digunakan didalam agen untuk menghasilkan kesimpulan dari persepsi-persepsi yang datang, seringkali tanpa query yang spesifik Akil, Ibnu (2017).

\subsection{Sistem Pakar}

Sistem pakar adalah program komputer yang merepresentasikan dan melakukan penalaran dengan pengetahuan dari seseorang pakar dalam bidang tertentu dengan pandangan untuk memecahkan masalah atau memberikan nasihat. Pakar menusia (human expert) adalah seseoran yang mempunyai penguasaan yang mendalam terhadap suatu masalah. Berdasarkan pengalamannya, pakar manusia mengembangkan kemampuannya dalam memecahkan masalah secara lebih efisien dan efektif. Sistem pakar jugaharus dapat menjelaskan alasan dari setiap langkah dalam mencapai suatu tujuan (goal) dan menjawab pertanyaan tentang solusi yang dicapainya, seperti halnya seseorang pakar manusia Hayadi, H. (2016).

\subsection{Visual Basic.net}

Microsoft Visual Basic .NET adalah sebuah alat untuk mengembangkan dan membangun aplikasi yang bergerak platform .NET Framework, dengan menggunakan bahasa BASIC. Maka dari itu Dengan menggunakan alat ini, para programmer dapat dan juga dapat membangun aplikasi Windows Forms, Aplikasi web berbasis ASP.NET, dan juga aplikasi command-line. Alat ini dapat diperoleh secara terpisah dari beberapa produk lainnya (seperti Microsoft Visual C++,Visual C\#, atau Visual $\mathrm{J} \#)$, atau juga dapat diperoleh secara terpadu 
dalam Microsoft Visual Studio .NET. Bahasa Visual Basic .NET sendiri menganut paradigma bahasa pemrograman berorientasi objek yang dapat dilihat sebagai evolusi dari Microsoft Visual Basic versi sebelumnya yang di implementasikan di atas Framework. Peluncurannya mengundang kontroversi, mengingat banyak sekali perubahan yang dilakukan oleh Microsoft, dan versi baru ini tidak kompatibel dengan versi terdahulu Johnson, Bruce (2013).

\section{$2.5 \quad X A M P P$}

$X A M P P$ adalah perangkat lunak bebas, yang mendukung banyak sistem operasi, merupakan kompilasi dari beberapa program. Fungsinya adalah sebagai server yang berdiri sendiri (localhost), yang terdiri atas program Apache HTTP Server, MySQL database, dan penerjemah bahasa yang ditulis dengan bahasa pemrograman PHP dan Perl. Nama XAMPP merupakan singkatan dari X (sistem operasi apapun), Apache, MySQL, PHP dan Perl. Program ini tersedia dalam GNU General Public License dan bebas, merupakan web server yang mudah digunakan yang dapat melayani tampilan halaman web yang dinamis Indrawan, M. L. (2013).

\section{Metodologi Penelitian}

Metode air terjun atau yang sering disebut metode waterfall sering dinamakan siklus hidup klasik (classic life cycle), dimana hal ini menggambarkan pendekatan yang sistematis dan juga berurutan pada pengembangan perangkat lunak.

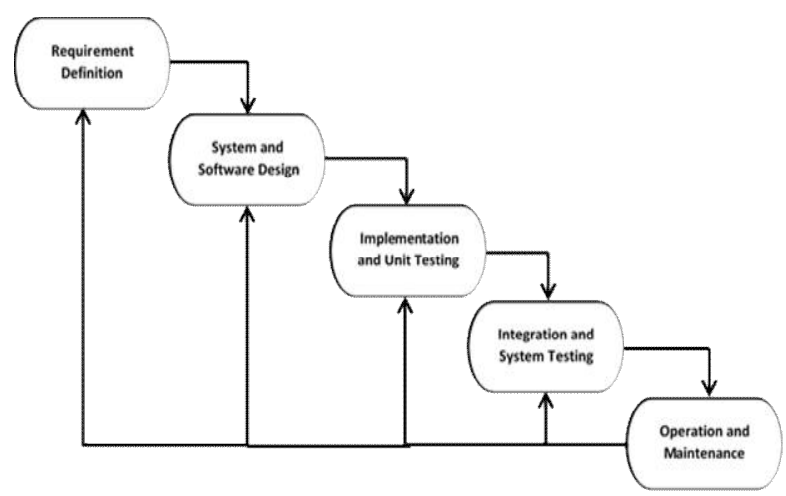

Gambar 1. Metode Waterfall

\subsection{Requirement Definition}

Requirement Definiton merupakan langkah dalam mendefinisikan kebutuhan yang diperlukan dalam penelitian seperti kebutuhan data system. Kebutuhan data system didapatkan melalui beberapa langkah. Berikut merupakan langkah-langkah dalam mendapatkan kebutuhan data system:

\subsubsection{Studi Literatur}

Didalam tahapan ini, penelitian dilakukan dengan cara mempelajari berbagai literatur melalui pengumpulan data melalui dokumen, referensi, buku dan sumber yang berasal dari internet yang memiliki kaitan dengan topik penelitian.

\subsubsection{Wawancara}

Wawancara dilakukan terhadap pakar untuk mendapatkan informasi yang dibutuhkan dalam pengembangan sistem pakar forward chaining untuk identifikasi dan tindakan perawatan jerawat wajah seperti jenis penyakit, jenis gejala serta mencari kebenaran informasi. Didalam wawancara juga memastikan bentuk penerapan metode forward chaining terhadap sistem.

\subsubsection{Observasi}

Observasi merupakan kegiatan yang dilakukan untuk mengambil data langsung dari tempat yang memiliki kaitan dengan penelitian.

\subsection{System and Software Design}

Proses berikutnya merupakan pembuatan desain sistem dan software. Proses tersebut merupakan langkah berfokus pada desain pembuatan program perangkat lunak termasuk struktur data meliputi database yang digambarkan dengan DFD, ERD dan kebutuhan pengguna yang digambarkan dengan WBS serta Use Case sebagai keperluan pada kebutuhan penelitian.

\subsection{Implementation and Unit Testing}

Dalam implementasi sistem, dilakukan berdasarkan dari perancangan aplikasi. Proses implementasi dilakukan dengan mengimplementasikan analisa kebutuhan perangkat sebagai penunjang diantaranya pemrograman Visual Basic, basisdata SQL Server, serta tools yang akan digunakan dalam pembuatan sistem, data gejala jerawat, data mengenai jenis jerawat, data mengenai tindakan perawatan jerawat.

\subsection{Integration and System Testing}

Pengujian dilakukan berdasarkan tujuan dari rumusan masalah. Pengujian dilakukan dengan cara 
membangun sebuah prototype aplikasi sistem pakar dan pengujian dengan mencoba sistem apakah telah sesuai dengan hasil solusi dari pakar.

\subsection{Evaluasi Sistem}

Evaluasi sistem dilakukan ketika terdapat kesalahan pada sistem yang berjalan atau tambahan pada data yang telah di verifikasi oleh pakar.

\section{Analisis Dan Perancangan}

\subsection{Analisa dan perancangan}

Pada bab ini diuraikan dengan rancangan sistem yang meliputi rancangan model, rancangan arsitektur sistem, rancangan proses, rancangan data dan rancangan antarmuka pengguna (user interface). Berikut adalah tabel nama penyakit dan tabel gejala dan yang terdapat pada tabel 1 dan tabel 2 .

Table 1. Tabel Penyakit

\begin{tabular}{|l|l|}
\hline Kode Penyakit & Nama Penyakit \\
\hline $\mathrm{Pe} 01$ & Acne Vulgaris \\
\hline $\mathrm{Pe} 02$ & Rosacea \\
\hline $\mathrm{Pe} 03$ & Perioral dermatitis \\
\hline $\mathrm{Pe} 04$ & Pityrosporum folliculitis \\
\hline $\mathrm{Pe} 05$ & Keratosis pilaris \\
\hline $\mathrm{Pe} 06$ & $\begin{array}{l}\text { Gram-negative bacterical } \\
\text { folliculitis }\end{array}$ \\
\hline $\mathrm{Pe} 07$ & Pseudofolliculitis \\
\hline
\end{tabular}

Table 2. Tabel Gejala

\begin{tabular}{|l|l|}
\hline Kode Gejala & Nama Gejala \\
\hline Ge01 & Muncul papul \\
\hline Ge02 & Muncul pustule \\
\hline Ge03 & Muncul nodul \\
\hline Ge04 & $\begin{array}{l}\text { Predileksinya pada area wajah, } \\
\text { dada dan punggung }\end{array}$ \\
\hline Ge05 & $\begin{array}{l}\text { Pada umumnya muncul pada usia } \\
\text { remaja }\end{array}$ \\
\hline Ge06 & Kulit perih dan sensasi terbakar \\
\hline Ge07 & $\begin{array}{l}\text { Kemerahan pada kulit yang } \\
\text { permanen }\end{array}$ \\
\hline Ge08 & $\begin{array}{l}\text { Permukaan kulit menjadi kasar, } \\
\text { seperti membengkak }\end{array}$ \\
\hline Ge09 & $\begin{array}{l}\text { Masalah pada mata (mata } \\
\text { bengkak, kelopak mata memerah) }\end{array}$ \\
\hline Ge10 & $\begin{array}{l}\text { Predileksinya pada sentral wajah } \\
\text { yaitu hidung, pipi, dagu, kening }\end{array}$ \\
\hline Ge11 & \\
\hline
\end{tabular}

\begin{tabular}{|c|c|}
\hline Kode Gejala & Nama Gejala \\
\hline & dan alis \\
\hline Ge12 & $\begin{array}{l}\text { Pada umumnya ditemukan pada } \\
\text { usia 30-40 tahun }\end{array}$ \\
\hline Ge13 & $\begin{array}{l}\text { Bintil kecil pada lipatan dagu } \\
\text { atau bagian bibir atas }\end{array}$ \\
\hline Ge14 & $\begin{array}{l}\text { Kulit berwarna merah dan } \\
\text { bersisik }\end{array}$ \\
\hline Ge15 & $\begin{array}{l}\text { Predileksinya pada area mulut, } \\
\text { bisa menyebar disekitar hidung } \\
\text { dan mata }\end{array}$ \\
\hline Ge16 & $\begin{array}{l}\text { Pada umumnya ditemukan pada } \\
\text { wanita muda }\end{array}$ \\
\hline Ge17 & Ada keluhan gatal \\
\hline Ge18 & $\begin{array}{l}\text { Muncul warna kemerahan yang } \\
\text { menyebar ke alis dan glabella }\end{array}$ \\
\hline Ge19 & $\begin{array}{l}\text { Sekumpulan benjolan merah atau } \\
\text { benjolan benjolan kecil berisi } \\
\text { nanah yang berkembang disekitar } \\
\text { folikel rambut }\end{array}$ \\
\hline Ge20 & $\begin{array}{l}\text { Predileksinya pada area } \\
\text { punggung, bahu, dan dada bagian } \\
\text { atas, bisa meluas sampai ke leher, } \\
\text { lengan atas dan wajah }\end{array}$ \\
\hline Ge21 & $\begin{array}{l}\text { Pada umumnya ditemukan pada } \\
\text { laki-laki atau perempuan usia 13- } \\
45 \text { tahun }\end{array}$ \\
\hline Ge22 & $\begin{array}{l}\text { Permukaan kulit kasar, tidak rata } \\
\text { atau bersisik }\end{array}$ \\
\hline $\mathrm{Ge} 23$ & $\begin{array}{l}\text { Predileksinya pada area kulit } \\
\text { lengan, paha, pipi, bokong. Bisa } \\
\text { muncul di wajah, alis atau kulit } \\
\text { kepala }\end{array}$ \\
\hline $\mathrm{Ge} 24$ & $\begin{array}{l}\text { Pada umumnya ditemukan pada } \\
\text { anak-anak dan remaja }\end{array}$ \\
\hline Ge25 & $\begin{array}{l}\text { Benjolan yang bengkak, besar } \\
\text { dan bernanah }\end{array}$ \\
\hline Ge26 & $\begin{array}{l}\text { Pada umumnya ditemukan pada } \\
\text { laki-laki dewasa }\end{array}$ \\
\hline Ge27 & Peradangan pada wajah dan leher \\
\hline $\mathrm{Ge} 28$ & $\begin{array}{l}\text { Pada umumnya ditemukan pada } \\
\text { segala umur }\end{array}$ \\
\hline
\end{tabular}

\subsection{Pohon Keputusan}

Pohon keputusan digunakan sebagai dasar membangun kumpulan aturan yang diperlukan untuk memprediksi penyakit jerawat wajah berdasarkan gejala-gejala yang ada Yulianti, M., A. (2012). 


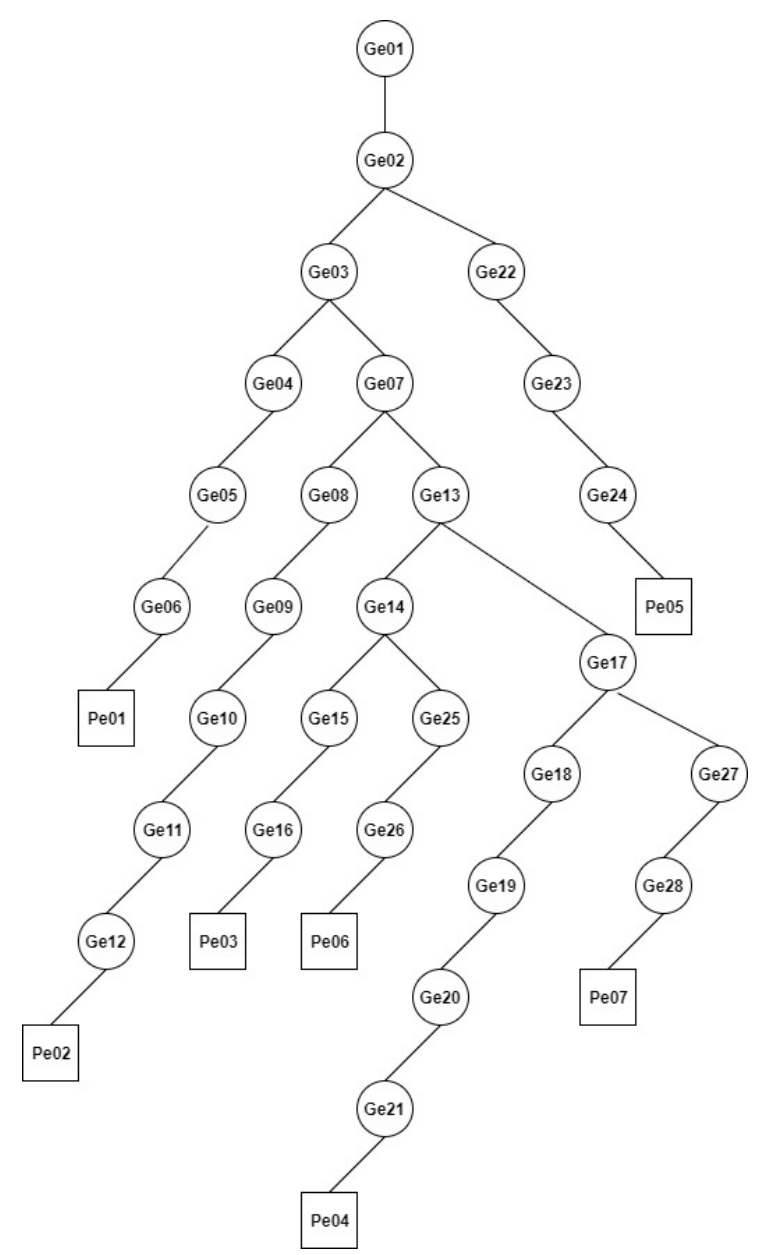

Gambar 2. Pohon Keputusan

\subsection{Aturan Forward Chaining}

Berikut adalah aturan (rule) dari metode forward chaining yang telah digambarkan pada pohon keputusan.

Table 3. Aturan Forward Chaining

\begin{tabular}{|c|c|l|}
\hline Rule & IF & \multicolumn{1}{c|}{ THEN } \\
\hline 1 & Pe01 & $\begin{array}{l}\text { Ge01, Ge02, } \\
\text { Ge03,Ge04,Ge05,Ge06 }\end{array}$ \\
\hline 2 & Pe02 & $\begin{array}{l}\text { Ge01, Ge02, Ge07, Ge08, Ge09, } \\
\text { Ge10, Ge11, Ge12 }\end{array}$ \\
\hline 3 & Pe03 & $\begin{array}{l}\text { Ge01, Ge02, Ge13, Ge14, Ge15, } \\
\text { Ge16 }\end{array}$ \\
\hline 4 & Pe04 & $\begin{array}{l}\text { Ge01, Ge02, Ge17, Ge18, Ge19, } \\
\text { Ge20, Ge21 }\end{array}$ \\
\hline 5 & Pe05 & $\mathrm{Ge} 01, \mathrm{Ge} 22, \mathrm{Ge} 23, \mathrm{Ge} 24$ \\
\hline 6 & $\mathrm{Pe} 06$ & $\mathrm{Ge} 01, \mathrm{Ge} 02, \mathrm{Ge} 13, \mathrm{Ge} 25, \mathrm{Ge} 26$ \\
\hline 7 & $\mathrm{Pe} 07$ & $\mathrm{Ge} 01, \mathrm{Ge} 02, \mathrm{Ge} 27, \mathrm{Ge} 28$ \\
\hline
\end{tabular}

\subsection{Perancangan Data}

\subsubsection{Flowchart Forward Chaining}

Berikut adalah gambar 3 yang merupakan Flowchart Forward Chaining yang akan dirancang dan memiliki beberapa tahapan-tahapan.

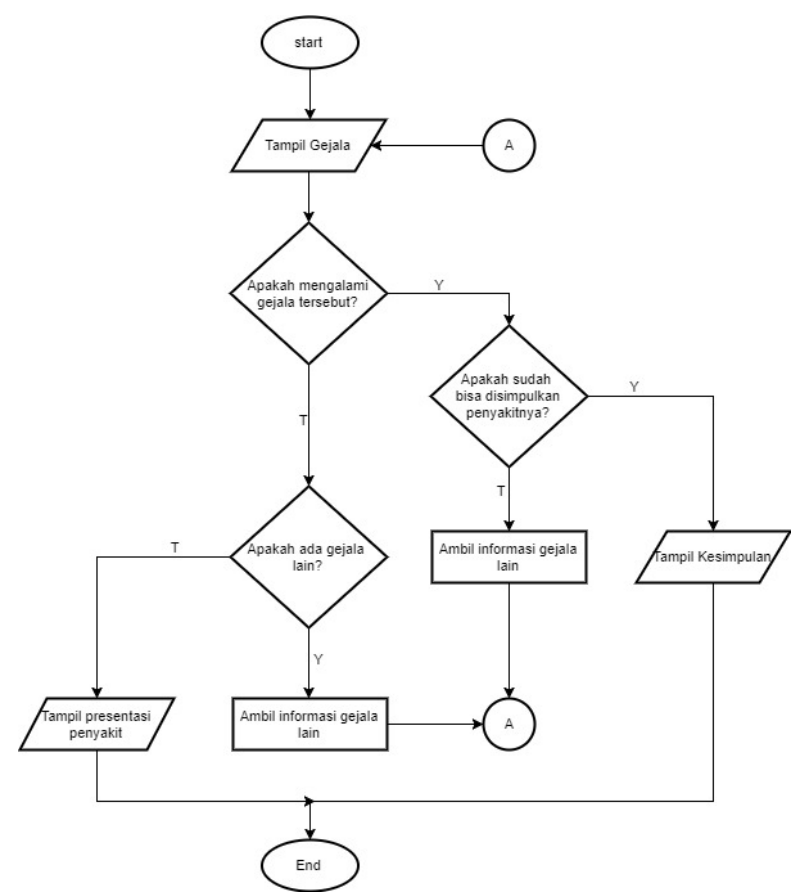

Gambar 3. Flowchart Forward Chaining

\subsubsection{Context Diagram}

DFD Level 0 atau context diagram biasa disebut sebagai diagram sistem inti (fundamental system model) atau biasa model konteks (context model). Arah panah dari aliran data menunjukkan aliran data berupa masukan (input) dan keluaran (output) ke dalam proses perangkat lunak yang dirancang. DFD level 0 dalam perancangan sistem ini memiliki sebuah proses besar yang nantinya akan diuraikan menjadi proses-proses yang lebih kecil dalam DFD level 1. Berikut adalah gambar context diagram yang terdapat pada gambar 4 .

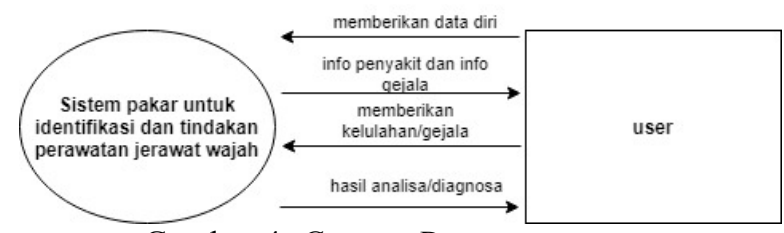

Gambar 4. Context Diagram 


\section{Implementasi}

\subsection{Implementasi Database}

Pada bab ini dijelaskan mengenai database yang digunakan. Berdasarkan perancangan basis data yang telah dilakukan, maka dibuatlah database dengan nama skripsi dengan struktur database.

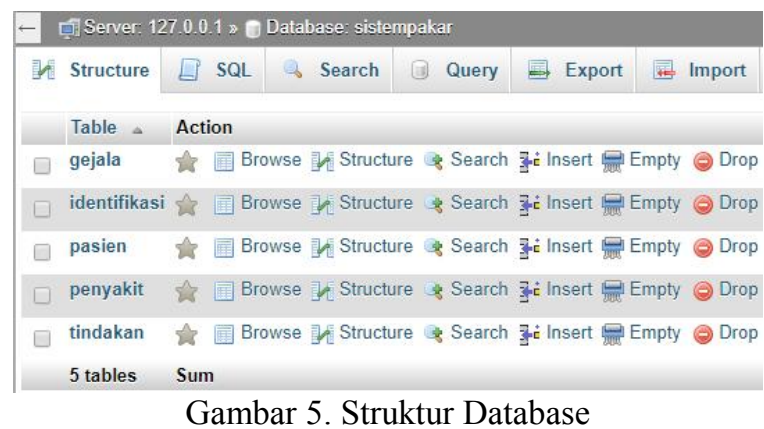

\subsection{Implementasi Sistem}

Berikut adalah gambar menu identifikasi :

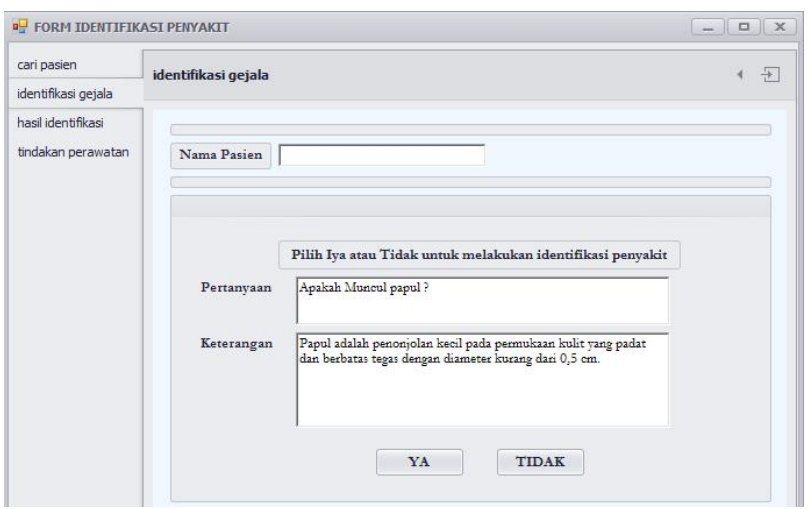

Gambar 6. Menu Identifikasi

Menu identifikasi ini merupakan menu utama dari aplikasi sistem pakar ini. Dimana pada menu ini berfungsi untuk proses identifikasi dan tindakan perawatan jerawat wajah dengan menggunakan rule dari metode forward chaining.

\section{Pengujian}

\subsection{Pengujian Fungsional}

Berikut adalah tabel 4 yang menunjukkan pengujian fungsional dari sistem pakar.
Tabel 4. Tabel Pengujian Fungsional

\begin{tabular}{|c|c|c|}
\hline Pengujian & Hasil Diharapkan & $\begin{array}{c}\text { Hasil } \\
\text { Pengujian }\end{array}$ \\
\hline $\begin{array}{l}\text { Button } \\
\text { tambah }\end{array}$ & $\begin{array}{l}\text { Menampilkan } \\
\text { Message box"Data } \\
\text { baru tersimpan" } \\
\text { apabila berhasil. }\end{array}$ & Sesuai \\
\hline Button ubah & $\begin{array}{l}\text { Menampilkan } \\
\text { Message box"Data } \\
\text { berhasil di update" } \\
\text { apabila berhasil. }\end{array}$ & Sesuai \\
\hline Button hapus & $\begin{array}{l}\text { Menampilkan } \\
\text { Message box"Data } \\
\text { berhasil di hapus" } \\
\text { apabila berhasil. }\end{array}$ & Sesuai \\
\hline Button detail & $\begin{array}{l}\text { Menampilkan gambar } \\
\text { beserta keterangan } \\
\text { gejala dan penyakit } \\
\text { apabila berhasil. }\end{array}$ & Sesuai \\
\hline Button ya & $\begin{array}{l}\text { Memunculkan } \\
\text { pertanyaan } \\
\text { selanjutnya. }\end{array}$ & Sesuai \\
\hline Button tidak & $\begin{array}{l}\text { Memunculkan } \\
\text { pertanyaan } \\
\text { selanjutnya. }\end{array}$ & Sesuai \\
\hline $\begin{array}{l}\text { Button } \\
\text { pengobatan }\end{array}$ & $\begin{array}{l}\text { Menampilkan hasil } \\
\text { identifikasi dan } \\
\text { tindakan pengobatan } \\
\text { penyakit. }\end{array}$ & Sesuai \\
\hline $\begin{array}{l}\text { Button } \\
\text { refresh }\end{array}$ & $\begin{array}{l}\text { Mengosongkan data } \\
\text { pada menu tindakan } \\
\text { perawatan. }\end{array}$ & Sesuai \\
\hline
\end{tabular}

\subsection{Pengujian Akurasi}

Pengujian akurasi dilakukan untuk menemukan persentase ketepatan dalam proses pengklasifikasian terhadap data testing yang diuji. Tingkat akurasi dihitung dengan menggunakan rumus Prasetyo, dkk (2014).

$$
\text { Akurasi }=\frac{\Sigma m a t c h}{\Sigma t p} \times 100 \%
$$

$\sum$ match $=$ jumlah klasifikasi yang benar $\sum \mathrm{tp}=$ jumlah data testing

Berikut adalah tabel 5 yang menunjukkan tabel pengujian akurasi terhadap user:

Tabel 5. Pengujian Akurasi

\begin{tabular}{|l|l|l|l|l|}
\hline No & Pasien & $\begin{array}{l}\text { Diagnosa } \\
\text { Pasien }\end{array}$ & $\begin{array}{l}\text { Diagnosa } \\
\text { Pakar }\end{array}$ & Akurasi \\
\hline 1 & $\begin{array}{l}\text { Pasien } \\
\text { A }\end{array}$ & $\begin{array}{l}\text { Acne } \\
\text { Vulgaris }\end{array}$ & $\begin{array}{l}\text { Acne } \\
\text { Vulgaris }\end{array}$ & 1 \\
\hline
\end{tabular}




\begin{tabular}{|c|c|c|c|c|}
\hline No & Pasien & $\begin{array}{l}\text { Diagnosa } \\
\text { Pasien }\end{array}$ & $\begin{array}{l}\text { Diagnosa } \\
\text { Pakar }\end{array}$ & Akurasi \\
\hline 1 & $\begin{array}{l}\text { Pasien } \\
\text { A }\end{array}$ & $\begin{array}{l}\text { Acne } \\
\text { Vulgaris }\end{array}$ & $\begin{array}{l}\text { Acne } \\
\text { Vulgaris }\end{array}$ & 1 \\
\hline 2 & $\begin{array}{l}\text { Pasien } \\
\text { B } \\
\end{array}$ & $\begin{array}{l}\text { Acne } \\
\text { Vulgaris }\end{array}$ & $\begin{array}{l}\text { Acne } \\
\text { Vulgaris }\end{array}$ & 1 \\
\hline 3 & $\begin{array}{l}\text { Pasien } \\
\mathrm{C}\end{array}$ & $\begin{array}{l}\text { Acne } \\
\text { Vulgaris }\end{array}$ & $\begin{array}{l}\text { Acne } \\
\text { Vulgaris }\end{array}$ & 1 \\
\hline 4 & $\begin{array}{l}\text { Pasien } \\
\text { D }\end{array}$ & $\begin{array}{l}\text { Kemungkin } \\
\text { an terkena } \\
\text { Acne } \\
\text { Vulgaris } \\
50 \%\end{array}$ & $\begin{array}{l}\text { Acne } \\
\text { Vulgaris }\end{array}$ & 0 \\
\hline 5 & $\begin{array}{l}\text { Pasien } \\
\text { E }\end{array}$ & $\begin{array}{l}\text { Acne } \\
\text { Vulgaris }\end{array}$ & $\begin{array}{l}\text { Acne } \\
\text { Vulgaris }\end{array}$ & 1 \\
\hline 6 & $\begin{array}{l}\text { Pasien } \\
\mathrm{F}\end{array}$ & $\begin{array}{l}\text { Acne } \\
\text { Vulgaris }\end{array}$ & $\begin{array}{l}\text { Acne } \\
\text { Vulgaris }\end{array}$ & 1 \\
\hline 7 & $\begin{array}{l}\text { Pasien } \\
\mathrm{G}\end{array}$ & $\begin{array}{l}\text { Acne } \\
\text { Vulgaris }\end{array}$ & $\begin{array}{l}\text { Acne } \\
\text { Vulgaris }\end{array}$ & 1 \\
\hline 8 & $\begin{array}{l}\text { Pasien } \\
\mathrm{H} \\
\end{array}$ & $\begin{array}{l}\text { Acne } \\
\text { Vulgaris }\end{array}$ & $\begin{array}{l}\text { Acne } \\
\text { Vulgaris }\end{array}$ & 1 \\
\hline 9 & $\begin{array}{l}\text { Pasien } \\
\text { I }\end{array}$ & $\begin{array}{l}\text { Kemungkin } \\
\text { an terkena } \\
\text { Gram- } \\
\text { negative } \\
\text { folliculitis } \\
33.3 \%\end{array}$ & $\begin{array}{l}\text { Acne } \\
\text { Vulgaris }\end{array}$ & 0 \\
\hline 10 & $\begin{array}{l}\text { Pasien } \\
\mathrm{J}\end{array}$ & $\begin{array}{l}\text { Acne } \\
\text { Vulgaris }\end{array}$ & $\begin{array}{l}\text { Acne } \\
\text { Vulgaris }\end{array}$ & 1 \\
\hline 11 & $\begin{array}{l}\text { Pasien } \\
\mathrm{K}\end{array}$ & $\begin{array}{l}\text { Acne } \\
\text { Vulgaris }\end{array}$ & $\begin{array}{l}\text { Acne } \\
\text { Vulgaris }\end{array}$ & 1 \\
\hline 12 & $\begin{array}{l}\text { Pasien } \\
\text { L }\end{array}$ & $\begin{array}{l}\text { Acne } \\
\text { Vulgaris }\end{array}$ & $\begin{array}{l}\text { Acne } \\
\text { Vulgaris }\end{array}$ & 1 \\
\hline
\end{tabular}

Berdasarkan tabel 5 telah dilakukan dengan 12 sempel data pasien dan menghasilkan akurasi sesuai perhitungan berikut:

Nilai Akurasi $=\frac{\Sigma m a t c h}{\Sigma t p} \times 100 \%$

Jadi nilai ke akurasian $=\frac{10}{12} \times 100 \%=83.3 \%$

Jadi dapat disimpulkan bahwa akurasi sistem pakar berdasarkan 12 data yang diuji adalah $83.3 \%$ yang menunjukkan bahwa sistem pakar ini berfungsi cukup baik sesuai dengan diagnosa pakar.

\section{Penutup}

\subsection{Kesimpulan}

Berdasarkan analisa dan perancangan, implementasi serta pengujian pengembangan sistem pakar forward chaining untuk identifikasi dan tindakan perawatan jerawat wajah, maka didapatkan kesimpulan sebagai berikut:

1. Hasil pengujian fungsional dan sistem menunjukan bahwa metode forward chaining dapat digunakan untuk mengembangkan sistem pakar identifikasi dan tindakan perawatan jerawat wajah yang diimplementasikan berbasis dekstop.

2. Sistem pakar yang telah dikembangkan dapat memberikan solusi dan memberikan informasi kepada orang awam dalam mengidentifikasi penyakit jerawat.

3. Berdasarkan hasil uji lapangan menggunakan aplikasi sistem pakar, didapatkan hasil persentase sebesar $83.3 \%$ yang menunjukkan bahwa aplikasi cukup efektif. Hasil penelitian ini menunjukan bahwa aplikasi sistem pakar ini dapat meningkatkan efektifitas dalam proses identifikasi jerawat wajah.

\section{$7.2 \quad$ Saran}

Pada penelitian ini ada beberapa saran yang dapat diberikan untuk pengembangan sistem selanjutnya meliputi:

1. Pemilihan penggunaan bahasa dalam sistem perlu dipertimbangkan agar lebih memudahkan pengguna sistem, khususnya penggunaan bahasa medis dan bahasa asing.

2. Pengembangan sistem berbasis web dengan fitur tanya jawab dan diskusi online dengan pakar dokter spesialis kulit agar pengguna lebih mudah untuk berkonsultasi langsung dengan pakar.

\section{Daftar Pustaka:}

Prasetyo dan Catur. 2014. Analisis Metode Forward Chaining Dalam Sistem Pakar Diagnosa Penyakit Pada Hewan Sapi. Semarang: Jurnal Informatika

Huda, Syamsul. 2014. Acne/Jerawat. Surabaya: Universitas Airlangga

Miller, Laurence, 2014. What Is Acne. Bethesda: National Institute of Arthritis and Musculoskeletal and Skin Diseas

Miller, Laurence, 2014. What Is Rosacea. Bethesda: National Institute of Arthritis and Musculoskeletal and Skin Diseas

Miller, Laurence, 2014. What Is Perioral dermatitis. Bethesda: National Institute of Arthritis and Musculoskeletal and Skin Diseas

Sharquie, E Khalifa. dkk. 2012. Malassezia Folliculitis Versus Truncal Acne Vulgaris. Basrah: Journal of Cosmetics, Dermatological Sciences and Applications, 2012, 2, 277-282 
Hospenthal, Tania Von, 2014. Keratosis Pilaris. London: British Association of Dermatologists

Daniella, Sierra Tellez. dkk. 2011. Gram-Negative Folliculitis A Rare Or Is It Underdiagnosed. Mexico: N Dermatol Online, 2011; 213: 135138

Hospenthal, Tania Von, 2014. Pseudofolliculitis. London: British Association of Dermatologists

Verina, Wiwi. 2015. Penerapan Metode Forward Chaining untuk Mendeteksi Penyakit THT. Medan: Jatisi, Vol.1 No.2 Maret 2015

Akil, Ibnu. 2017. Analisa Efektif Metode Forward Chaining dan Backward Chaining Pada Sistem Pakar. Jakarta: Jurnal Pilar Nusa Mandiri Volume 13. No 1 Maret 2017

Hayadi, Herawan. 2016. Sistem Pakar. Yogyakarta: Deepublish

Johnson, Bruce. 2013. Professional Visual Studio 2012. Indianapolis: John Wiley \& Sons.Inc

Indrawan, Muhammad Lutfi. 2013. "Tutorial XAMPP"

https://youthpatner.web.id / diakses pada tanggal 31 Desember 2016

Yulianti, Mewati Ayub. Sistem Pakar Diagnosis Penyakit Anjing dengan Forward Chaining. Bandung: Jurnal Informatika. Vol. 8, No.2, Desember 2012:127-140 
Volume 4, Edisi 1, November 2017

$\mathbf{8 0} \mid \mathrm{H}$ a 1 a $\mathrm{m}$ a $n$ 